\title{
Evaluation of Dry Matter, Protein, Starch, Sucrose, $\beta$-carotene, Iron, Zinc, Calcium, and Magnesium in East African Sweetpotato [Ipomoea batatas (L.) Lam] Germplasm
}

\author{
Silver Tumwegamire ${ }^{3}$ and Regina Kapinga ${ }^{1}$ \\ International Potato Center (CIP), P.O. Box 22274, Kampala, Uganda
}

Patrick R. Rubaihayo

Crop Science Department, Makerere University, P.O. Box 7062 Kampala, Uganda

\author{
Don R. LaBonte \\ Louisiana State University, AgCenter, 104B M.B. Sturgis Hall, LSU Campus, \\ Baton Rouge, LA 70803
}
Wolfgang J. Grüneberg, Gabriela Burgos, Thomas zum Felde, and Rosemary Carpio
International Potato Center, Apartado 1558, Lima 12, Peru

\author{
Elke Pawelzik \\ Institute of Agricultural Chemistry, Georg-August-University Göttingen, \\ Carl-Sprengel-Weg 1, 37075 Göttingen, Germany
}

\section{Robert O.M. Mwanga ${ }^{2}$ \\ National Agricultural Research Organization (NARO), National Crops Resources Research Institute (NaCRRI), Namulonge, P.O. Box 7084, Kampala, Uganda}

Additional index words. biofortified crops, protein, starch, sucrose, $\beta$-carotene, iron, zinc, calcium, and magnesium contents, near-infrared reflectance spectroscopy (NIRS) technology, Ipomoea batatas

\begin{abstract}
The present study evaluated selected East African (EA) sweetpotato varieties for storage root dry matter and nutrient content and obtained information on the potential contributions of the varieties to alleviate vitamin $A$ and mineral deficiencies. Roots obtained from 89 farmer (white- and orange-fleshed) varieties and one introduced variety ('Resisto') were analyzed for storage root quality using near-infrared reflectance spectroscopy technology. Location differences were only significant for starch content. The $\sigma_{G}^{2}$ variance was significant $(\boldsymbol{P}<0.01)$ for all the traits except sucrose content. Overall, the farmer varieties had higher dry matter, higher starch, and lower sucrose contents than the control clone, 'Resisto'. It is these qualities that make sweetpotato attractive as a starchy staple in EA. A low population's mean $\beta$-carotene content (19.0 ppm) was observed. However, deep orange-fleshed farmer varieties, 'Carrot_C', 'Ejumula', 'Carrot Dar', 'Mayai', and 'Zambezi', had $\beta$-carotene content that can meet $350 \%$ or greater of recommended daily allowance (RDA) with 250 -g serving to a 5- to 8-year-old child. More but light orange-fleshed farmer varieties 'K-118', 'K-134', 'K-46', 'KMI61', 'MLE162 Nakahi', 'PAL161', 'Sowola6', 'Sponge', 'SRT34 Abuket2', 'SRT35 Anyumel', 'SRT52', and 'Sudan' can provide $50 \%$ to $90 \%$ RDA of pro-vitamin A for the child. The root minerals' content was generally low except for magnesium whose content can meet $50 \%$ or greater RDA in many farmer varieties. However, in areas with high sweetpotato consumption, varieties 'Carrot_C', 'Carrot Dar', 'KRE nylon', 'MLE163 Kyebandula', and 'SRT49 Sanyuzameza' can make good intakes of iron, zinc, calcium, and magnesium. In conclusion, some EA farmer varieties can contribute greatly to alleviation of vitamin A deficiency and substantial mineral intakes.
\end{abstract}

Sweetpotato [Ipomoea batatas (L.)] ranks fifth in importance for its caloric contribution in developing countries after rice, wheat, maize, and cassava (CIP, 2005). In some areas of EA, the crop has become a staple (Scott et al., 2000). For example, in Uganda, the daily intake of sweetpotato is estimated to be $240 \mathrm{~g} \cdot \mathrm{d}^{-1}$ per person (FAOSTAT, 2007). Information about quality attributes of African sweetpotato germplasm is very limited. The average storage root dry matter $(\mathrm{DM})$ of the cultivated sweetpotato clones of the world is $\approx 30 \%$ (Bradbury and Holloway, 1988; Woolfe, 1992). Two main taste groups can be distinguished: 1) white- and cream-fleshed sweetpotatoes usually with DM contents of $\approx 25 \%$ to $35 \%$; and 2) orangefleshed sweetpotatoes (OFSP) with DM of $\approx 20 \%$ to $30 \%$ and high provitamin A carotenoids (Grüneberg et al., 2009; Martin and Jones, 1986). The taste preference in sub-Saharan Africa is clearly the dry and low sweet type, which is nearly exclusively white-fleshed.

Carotenoid pigments provide OFSP storage roots the orange flesh color. More than $60 \mathrm{mg}$ total carotenoids in $100 \mathrm{~g} \mathrm{DM}$ have been reported (Woolfe, 1992). A constant high proportion $(\approx 90 \%)$ of $\beta$-carotene in relation to total carotenoids in OFSP has been known for decades (Ezell and Wilcox, 1958; Hagenimana et al., 1999; Purcell, 1962; Purcell and Walter, 1968), and currently OFSP is considered a complementary food approach to alleviate vitamin A deficiency (VAD) in the world (Low et al., 2001, 2007). Modern OFSP varieties that are more adapted to African consumer preferences than traditional moist and sweet OFSP have been bred and released in Uganda (Mwanga et al., 2007, 2009). Also, OFSP farmer varieties that meet local consumer preferences have been found in EA (CIP, 2005; Tumwegamire et al., 2004). Approximately $80 \%$ to $90 \%$ of sweetpotato storage root DM is made up of carbohydrates, mainly starch $(\approx 60 \%$ to $70 \%$ of DM) and sugars $(\approx 15 \%$ to $20 \%$ of DM with a wide range from $\approx 5 \%$ to $40 \%$ of DM), and lesser amounts of pectins, hemicelluloses and cellulose (Woolfe, 1992). Usually white- and cream-fleshed varieties have higher starch $(\approx 50 \%$ to $80 \%$ of DM) and lower sugar contents ( $\approx 5 \%$ to $15 \%$ of DM) compared with OFSP genotypes, which have lower starch $(\approx 45 \%$ to $55 \%$ of $\mathrm{DM})$ and higher sugar contents $(\approx 10 \%$ to $20 \%$ of DM) (Woolfe, 1992). Additionally, the storage root of sweetpotato also contains reasonable amounts of protein $[\approx 5 \%$ of storage root DM] (Woolfe, 1992). Studies on sweetpotato storage root mineral contents (especially trace minerals) are limited, particularly for African sweetpotato germplasm. Bradbury and Holloway (1988) reported storage root mineral content ranges of $\approx 75$ to $740 \mathrm{ppm}$ calcium, $\approx 180$ to $350 \mathrm{ppm}$ magnesium, $\approx 1.6$ to $9.4 \mathrm{ppm}$ iron, and $\approx 2.7$ to $18.9 \mathrm{ppm}$ zinc in sweetpotato accessions from the South Pacific. Courtney (2007) observed up to $\approx 10 \mathrm{ppm}$ iron and $\approx 6.4 \mathrm{ppm}$ zinc in fresh storage roots for North American breeding material.

The provitamin A and minerals (iron, zinc, calcium, and magnesium) are critical and deficient in human food supply (Frossard et al., 2000; Munoz et al., 2000). In Uganda, $\approx 20 \%$ of children and $19 \%$ of women are vitamin A-deficient and $73 \%$ of children and $49 \%$ of women are anemic (Uganda Bureau of Statistics and Macro International Inc., 2007). The levels of anemia are higher among pregnant (64\%) and breast-feeding (53\%) mothers. Worldwide, 127 million preschool children 
and more than 7.2 million pregnant women in developing countries suffer from VAD (Bouis, 2003; West, 2002) and approximately two billion people are anemic (Frossard et al., 2000). Another 13.5 million pregnant women have low vitamin A status (West, 2002). Globally, 800,000 and 700,000 deaths per year are attributed to iron (Fe) and zinc ( $\mathrm{Zn})$ deficiencies, respectively (Black, 2003). According to Black (2003), $2.4 \%, 1.8 \%$, and $1.9 \%$ of the global disease burden is attributable to Fe deficiency, vitamin A deficiency and $\mathrm{Zn}$ deficiency, respectively. OFSPs have been demonstrated to have a great potential to alleviate VAD around the Lake Victoria region and East African highlands (Low et al., 2001). However, the majority of sweetpotato varieties consumed in EA are white-fleshed. Also, the traditional OFSP with their moist and sweet taste are unlikely to be accepted on a broad basis in EA. Fortunately, African OFSP farmer varieties and modern breeding lines have been identified and are currently being promoted by CIP and HarvestPlus in Uganda and Mozambique (Mwanga et al., 2009). The present study evaluated selected East African sweetpotato accessions for storage root quality (DM, protein, starch, sucrose, $\beta$-carotene, $\mathrm{Fe}, \mathrm{Zn}$, calcium, and magnesium) and obtained information on the potential contributions of the accessions to alleviate vitamin A and mineral deficiencies in the EA region.

\section{Materials and Methods}

Ninety sweetpotato accessions were used in this study (Table 1). All varieties were farmer varieties from EA, except the modern variety 'Resisto' from the United States. Non-Ugandan accessions had been introduced in Uganda for regional trials during early 2005 in the frame of the sweetpotato biofortification project of the International Potato Center funded by the HarvestPlus Program. The variety, 'Resisto', was used in this study as a control to compare OFSP varieties of African origin with the typical moist and sweet OFSP type of nonAfrican origin. It should be noted that several nutritional studies have used 'Resisto' to

Received for publication 25 Aug. 2010. Accepted for publication 8 Dec. 2010.

This research was part of CIP's sweetpotato biofortification breeding project funded under the HarvestPlus Biofortification challenge Program. We obtained the sweetpotato germplasm used in the study from different national sweetpotato programs in Uganda, Kenya, Tanzania, and Zambia.

This paper is part of a $\mathrm{PhD}$ thesis submitted to Makerere University, Kampala, Uganda, by Tumwegamire Silver.

${ }^{1}$ Former Regional Sweetpotato Breeder for subSaharan Africa; currently program officer, Bill Gates Foundation Seattle, USA.

${ }^{2}$ Former Team Leader Sweepotato Research, NARO; currently the Regional Sweetpotato Breeder East and Central Africa, International Potato Centre, Uganda.

${ }^{3}$ To whom reprint requests should be addressed; e-mail s.tumwegamire@cgiar.org. investigate effects on human vitamin A status resulting from OFSP consumption (Low et al., 2007; van Jaarsveld et al., 2005). Thirty-two of the farmer varieties were OFSP cultivars with varied intensities of orange flesh color. One cultivar, Kwezikumwe, was purple-fleshed. The remaining accessions were cream-, white-, or yellow-fleshed varieties. Sixty-five farmer varieties were from Uganda, 19 from Kenya, four from Tanzania, and one from Zambia.

The field trials were planted at the National Crops Resources Research Institute at Namulonge close to lake Victoria (1150 m.a.s.l.), and Kachwekano Zonal Agricultural Research Institute (2220 m.a.s.1.) in the southwestern highlands of Uganda (Table 2). Namulonge has a bimodal rainfall pattern of $1270 \mathrm{~mm}$ per year, annual mean temperature of $22.2{ }^{\circ} \mathrm{C}$ (mean maximum temperature, $28.4^{\circ} \mathrm{C}$; mean minimum temperature, $15.9^{\circ} \mathrm{C}$ ), ferralitic soils (red sandy clay loams), and soil $\mathrm{pH} 4.9$ to 5.0. Kachwekano has a bimodal rainfall of $1319 \mathrm{~mm}$ per year, annual mean temperature of $18.0{ }^{\circ} \mathrm{C}$, latosolic soils (sandy clay loam), and soil $\mathrm{pH} 5.8$ to 6.2. During the second rain season of 2005 (starting in October), each landrace was planted on two-row plots using 20 vines placed $30 \mathrm{~cm}$ apart. The rows were $1 \mathrm{~m}$ apart and each variety was planted with two plot replications in a randomized complete block design. The plots were kept weed-free and no fertilizer or other agrochemicals were applied. Harvest was carried out 5 months after planting at Namulonge and 7 months after planting at Kachwekano using the local practice of sweetpotato crop duration in these different ecogeographic zones.

Plots were harvested by uprooting the center of each row, leaving a plant at both ends of each row. The harvested roots were collected into a composite pile and a sample of five roots each between 100 and $300 \mathrm{~g}$ weight was taken for DM, protein, starch, sucrose, $\beta$-carotene, $\mathrm{Fe}, \mathrm{Zn}$, calcium, and magnesium determination. The roots were washed of soil particles and rinsed with abundant tap water, peeled, and each root cut longitudinally into four sections. Two opposite sections of each of the sectioned roots were taken to prepare a 100-g compound sample that was placed in transparent polythene bags and freeze-dried at $-31{ }^{\circ} \mathrm{C}$ for $72 \mathrm{~h}$. Dry samples were weighed, milled into flour in a stainless steel mill, and stored in Kraft paper bags.

Percent root DM was calculated from flesh and dry weight estimates. Near-infrared reflectance spectroscopy (NIRS) technology (Shenk and Westerhaus, 1993) was used to determine protein, starch, sucrose, $\beta$-carotene, Fe, $\mathrm{Zn}$, calcium, and magnesium in milled samples of freeze-dried storage root samples. NIRS technology has been used to screen for macronutrients in root and tuber crops (Haase, 2006; Mehrübeoglu and Coté, 1997; Young et al., 1997;), including sweetpotato (Lebot et al., 2009; $\mathrm{Lu}$ et al., 2006), and has been tested for minerals in agricultural commodities (Cozzolino and Moron, 2004, Halgerson et al., 2004). Also the technology has become a standard fast screening method for mirconutrients (provitamins A, Fe, and Zn) (Pfeiffer and McClafferty,
2007, Zum Felde et al., 2009). Each milled sample material (two times $3 \mathrm{~g}$ ) was analyzed by NIRS within the range of 400 to $2500 \mathrm{~nm}$ on a NIRS monochromator model 6500 (NIRSystems, Inc., Silver Springs, MD) using small ring cups with a sample autochanger. Near-infrared spectra of each sample were stored in a computer file and in 2009 these spectra were again used to determine protein, starch, sucrose, $\beta$-carotene, $\mathrm{Fe}, \mathrm{Zn}$, calcium, and magnesium with the latest calibration version for sweetpotato freeze-dried samples (Zum Felde et al., 2009). In this version, the correlations in cross-validation between standard laboratory reference methods and NIRS are $0.95,0.96,0.80,0.97,0.80$, and 0.89 for protein, starch, sucrose, $\beta$-carotene, $\mathrm{Fe}, \mathrm{Zn}$, respectively (Zum Felde et al., 2009) and 0.92 and 0.78 for calcium and magnesium, respectively (Zum Felde, personal communication). The reference methods to develop the NIRS calibration were Dumas according to Sweeney and Rexroad (1987) for crude protein, polarimetrically by hydrochloric acid dissociation according to ICC No. 123/1 (ICC, 1994) for starch, high-performance liquid chromatography according to Rodriguez-Amaya and Kimura (2004) for $\beta$-carotene, inductively coupled plasma argon optical emission spectrometer, according to Bridger and Knowles (2000), and reviewed by Aceto et al. (2002) for Fe, $\mathrm{Zn}$, calcium, and magnesium. For sucrose determination, we used a procedure in which a water extract of the freeze-dried samples $(0.1 \mathrm{~g}$ in $100 \mathrm{~mL})$ was used: 1$)$ the samples were incubated in a water bath at $60^{\circ} \mathrm{C}$ for $1 \mathrm{~h}$ and afterward, they were treated with each 0.2-mL Carrez I and Carrez II solution to remove proteins; and 2) samples were purified by centrifugation (Sorvall RC-5B Refrigated Superspeed; GMI, Ramsay, NJ) for $10 \mathrm{~min}$ at $20{ }^{\circ} \mathrm{C}$ with $10000 \mathrm{rpm}$, total sugars were determined from the membrane-filtered supernatant (pores size $0.45 \mu \mathrm{m}$ ), and sucrose, glucose, fructose, maltose, and galactose were separated using a LiChrospher 100 $\mathrm{NH}_{2}(5 \mu \mathrm{m}) 4 \times 4 \mathrm{~mm}$ pre-column in combination with a LiChrospher $100 \mathrm{NH}_{2}(5 \mu \mathrm{m}) 4 \times$ $250 \mathrm{~mm}$ separation column (Merck KGaA, Darmstadt, Germany) and an acetonitrile-pure water solution $(80: 20 \mathrm{v} / \mathrm{v})$ as a mobile phase (flow rate $1.0 \mathrm{~mL} \cdot \mathrm{min}^{-1}$ ) at $20{ }^{\circ} \mathrm{C}$ and an injection volume of $20 \mu \mathrm{L}$. Sugars were detected with a Knauer differential refractometer 198.00 (Knauer, Berlin, Germany).

Statistical analyses were conducted using PLABSTAT (Plant Breeding Statistical Program) computer package (Utz, 2001) and SAS 6.12 (SAS Institute Inc., 1988, 1997). Data were classified relative to varieties or genotypes $(\mathrm{G})$, locations (L), and blocks or replications $(\mathrm{R})$. In an analysis of variance (ANOVA), each trait $x_{i}$ (namely, protein, starch, sucrose, $\beta$-carotene, Fe, $\mathrm{Zn}$, calcium, and magnesium) was analyzed from each experimental site separately to determine outliers, experimental means, coefficients of variation, and minimum and maximum values using the SAS procedure GLM and the model statement $x_{i}=\mathrm{G}+\mathrm{R}$, which corresponds to the statistical model: 


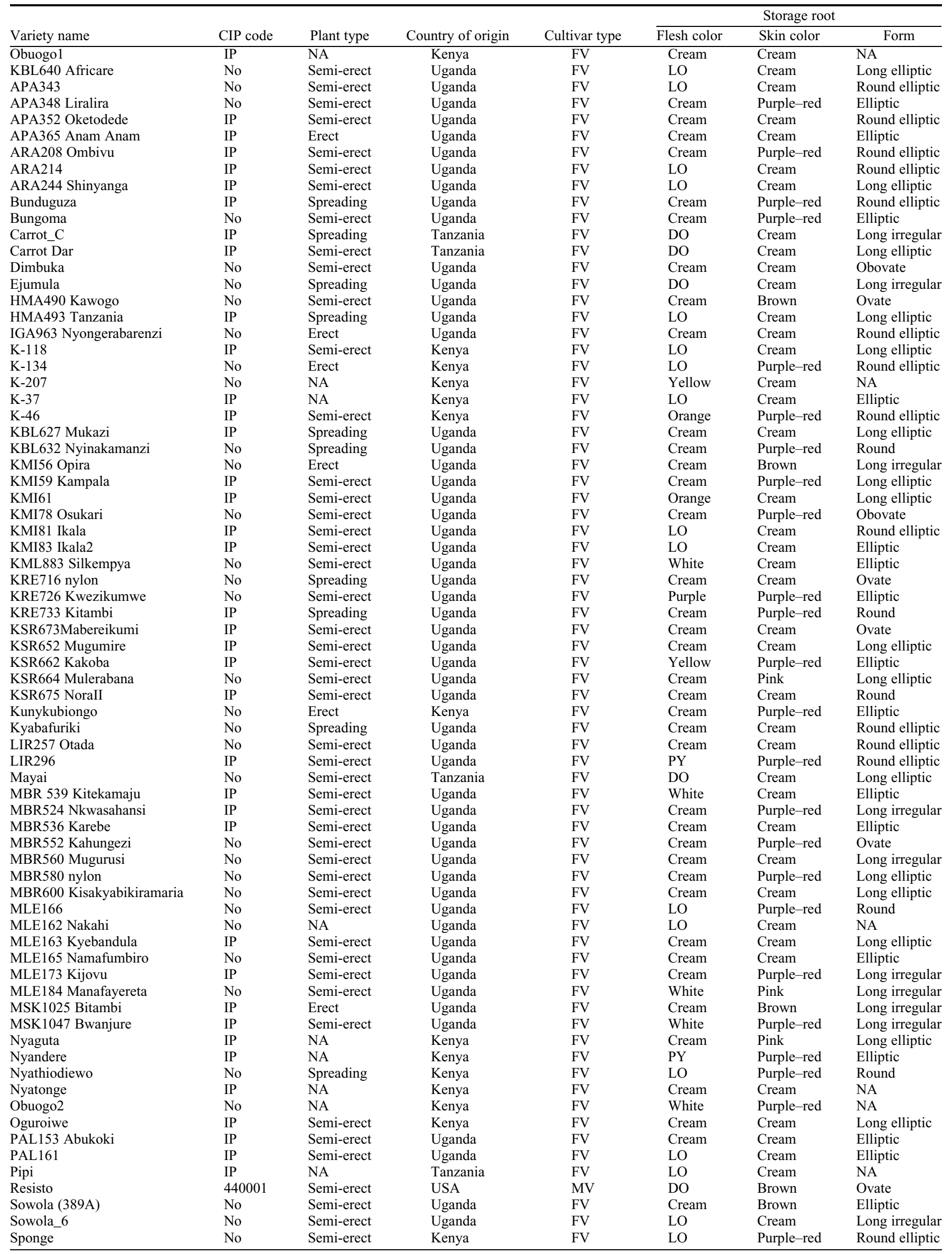


Table 1. (Continued) List of sweetpotato varieties used for quality characterization at Namulonge and Kachwekano in Uganda during 2005-2006.

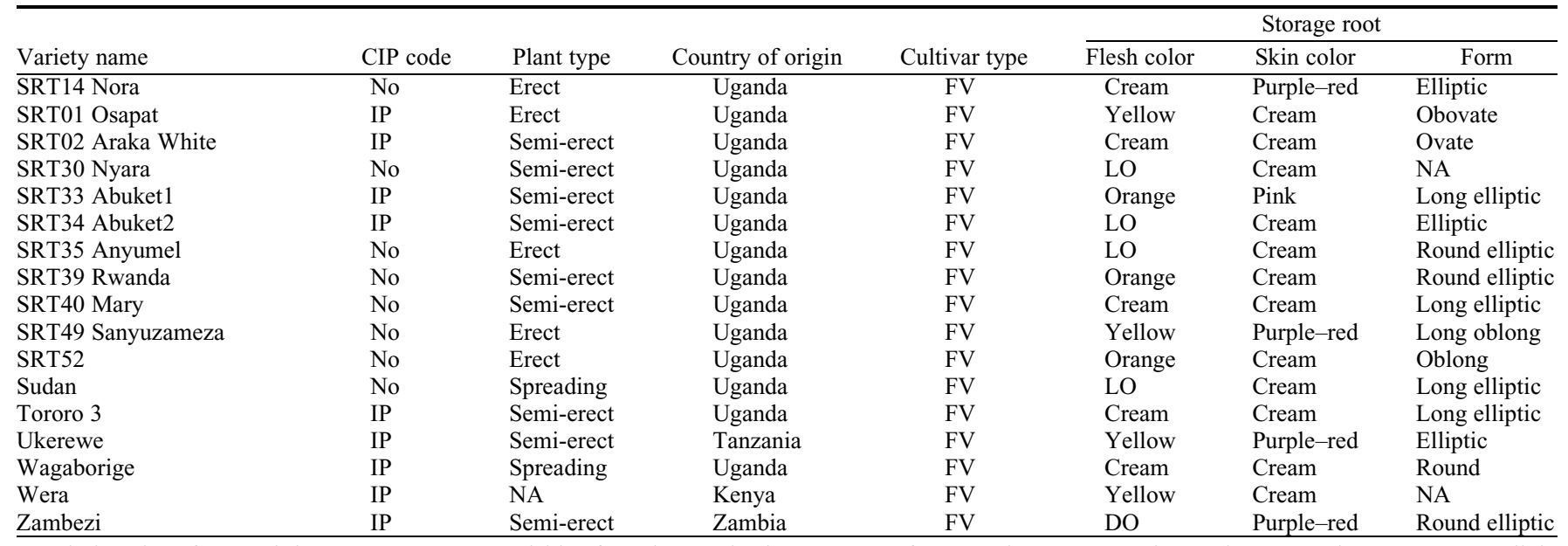

$\mathrm{IP}=$ designation of CIP code in process; $\mathrm{No}=$ no acquisition from the gene bank at $\mathrm{CIP} ; \mathrm{FV}=$ farmer variety; $\mathrm{MV}=$ modern variety; $\mathrm{DO}=$ deep orange; $\mathrm{LO}=$ light orange; $\mathrm{PY}=$ pale yellow; $\mathrm{NA}=$ not applicable.

$$
Y_{i j l}=\mu_{i}+g_{i j}+b l_{i l}+\varepsilon_{i j l},
$$

where $Y_{i j l}$ is the plot value of the $i$ th trait of the $j$ th genotype and the $l$ th block, $\mu_{i}$ is the trial mean of the $i$ th trait, $g_{i j}$ is the effect of genotypes, $b l_{i l}$ is the effect of blocks, and $\varepsilon_{i j l}$ is the plot error. For the analysis across locations an ANOVA was carried out for each trait $x_{i}$ using PLABSTAT with the model statement $x_{i}=\mathrm{G}+\mathrm{L}+\mathrm{EL}+\mathrm{R}: \mathrm{L}+\mathrm{RLG}$, which corresponds to the statistical model:

$$
Y_{i j k l}=\mu_{i}+g_{i j}+l_{i k}+g l_{i j k}+b l(l)_{i l(k)}+\varepsilon_{i j k l}
$$

where $1_{i k}$ and $g l_{i j k}$ are the effects of locations and genotype-location interactions, respectively, and other effects as designated previously. In the first analysis, all effects were considered random to use the ANOVA to estimate the magnitude and significance of variance components for $\sigma_{G}^{2}, \sigma_{L}^{2}, \sigma_{G x L}^{2}$, and $\sigma_{\varepsilon}^{2}$. In the second analysis, the effects $g_{i j}, 1_{i k}$, and $g l_{i j k}$ were considered as fixed to estimate the least significant difference (LSD) to compare means among varieties and locations for each trait.

Correlations among traits were carried out by SAS procedure CORR and the optional statement PEARSON. The correlations were calculated for each location and replication separately followed by calculating the average correlation between each trait pair across locations and replications using the statement BY in SAS procedure CORR. These correlations are still phenotypic correlations but can be considered as a good approximation of genotypic correlation estimates (Hill et al., 1998).

In the final analysis, the contribution of sweetpotato to the RDA for $\beta$-carotene, Fe, $\mathrm{Zn}$, calcium, and magnesium was calculated by assuming an intake of $250 \mathrm{~g}$ fresh sweetpotato storage root per day (comparable to the consumption estimates for Uganda). The RDAs for school-aged children from 5 to 8 years were based on the Institute of Medicine in the United States (National Academy of Sciences, 2004) statistics. These RDA per day are: $400 \mu \mathrm{g}$ retinol, which corresponds to $4.8 \mathrm{mg} \beta$-carotene, $10 \mathrm{mg} \mathrm{Fe}, 5 \mathrm{mg} \mathrm{Zn}, 800 \mathrm{mg}$ calcium, and 130 $\mathrm{mg}$ magnesium. For each, $\beta$-carotene, $\mathrm{Fe}, \mathrm{Zn}$,

Table 2. Description of locations used for the evaluation of farmer varieties.

\begin{tabular}{lcccccc}
\hline Location & $\begin{array}{c}\text { Ecogeographic } \\
\text { region }\end{array}$ & Soil types & $\begin{array}{c}\text { Altitude } \\
\text { (m.a.s.1.) }\end{array}$ & $\begin{array}{c}\text { Rainfall }^{\mathrm{z}} \\
(\mathrm{mm})\end{array}$ & \multicolumn{2}{c}{ Temperature $^{\mathrm{z}}\left({ }^{\circ} \mathrm{C}\right)$} \\
\hline Namulonge & $\begin{array}{c}\text { Tropical rain } \\
\text { forest }\end{array}$ & $\begin{array}{c}\text { Sandy clay soils } \\
\text { (pH 4.9 to 5.0) }\end{array}$ & 1150 & 359.0 & 23.1 & Range \\
Kachwekano & $\begin{array}{c}\text { Tropical } \\
\text { mountain region }\end{array}$ & $\begin{array}{c}\text { Sandy clay Loam } \\
\text { (pH 5.8 to 6.2) }\end{array}$ & 2220 & 423.1 & 18.1 & $11.9-24.2$ \\
\hline
\end{tabular}

${ }^{\mathrm{z}}$ Rainfall $(\mathrm{mm})$ and temperature experienced during the crop growing period: Oct. 2005 to Feb. 2006 at Namulonge and Oct. 2005 to Apr. 2006 at Kachwekano.

Table 3. Experimental means $(\bar{x}), \mathrm{cv}(\mathrm{cv} \%)$, minimum (min), and maximum (max) genotypic values for

\begin{tabular}{|c|c|c|c|c|c|c|c|c|}
\hline \multirow[b]{2}{*}{ Trait } & \multicolumn{4}{|c|}{ Namulonge } & \multicolumn{4}{|c|}{ Kachwekano } \\
\hline & $\bar{x}$ & $\mathrm{CV} \%$ & Min & Max & $\bar{x}$ & $\mathrm{CV} \%$ & Min & Max \\
\hline Storage root yield, $\mathrm{t} \cdot \mathrm{ha}^{-1}$ & 7.5 & 47.8 & 0 & 18.1 & 10.0 & 56.0 & 0.2 & 21.3 \\
\hline $\begin{array}{l}\text { Dry matter content } \\
\text { of storage roots, } \%\end{array}$ & 32.3 & 5.5 & 19.4 & 38.3 & 31.7 & 6.8 & 20.8 & 36.7 \\
\hline $\begin{array}{l}\text { Protein content of } \\
\text { storage roots, \% DM }\end{array}$ & 6.8 & 13.4 & 4.0 & 9.2 & 6.5 & 16.0 & 3.8 & 9.5 \\
\hline $\begin{array}{l}\text { Starch content of } \\
\quad \text { storage roots, \% DM }\end{array}$ & 60.5 & 3.2 & 30.1 & 68.2 & 68.2 & 3.2 & 62.2 & 73.4 \\
\hline $\begin{array}{l}\text { Sucrose content of } \\
\text { storage roots, \% DM }\end{array}$ & 11.4 & 14.6 & 4.3 & 48.7 & 9.4 & 18.0 & 4.7 & 13.8 \\
\hline $\begin{array}{l}\beta \text {-carotene content of } \\
\text { storage roots, ppm DM }\end{array}$ & 36 & 40.6 & 0 & 338 & 24 & 65.9 & 0 & 295 \\
\hline $\begin{array}{l}\text { Iron content of } \\
\text { storage roots, } \mathrm{ppm} \mathrm{DM}\end{array}$ & 23.7 & 8.9 & 17.3 & 33.2 & 19.5 & 11.1 & 14.7 & 26.9 \\
\hline $\begin{array}{l}\text { Zinc content of storage } \\
\text { roots, ppm DM }\end{array}$ & 12.3 & 11.0 & 9.5 & 17.8 & 9.5 & 12.1 & 5.9 & 12.7 \\
\hline $\begin{array}{l}\text { Calcium content of storage } \\
\text { roots, ppm DM }\end{array}$ & 1980 & 21.2 & 929 & 4411 & 1880 & 18.0 & 1029 & 3795 \\
\hline $\begin{array}{l}\text { Magnesium content of } \\
\text { storage roots, ppm DM }\end{array}$ & 569 & 25.4 & 169 & 1416 & 676 & 25.12 & 363 & 1392 \\
\hline
\end{tabular}
observed traits at locations.

$\mathrm{DM}=$ dry matter.

calcium, and magnesium data value, the corresponding percent RDA was calculated by: \% $\mathrm{RDA}=$ nutrient content in $250 \mathrm{~g}$ fresh weight basis (fwb)/RDA*100. To compare varieties for their value in RDA contribution, the LSDS were calculated for percent RDA as described for other traits previously mentioned.

\section{Results}

Differences in the experimental means between locations were not large for all the traits, except storage root starch content (Table 3 ). Storage root yield means were $7.5 \mathrm{t} \cdot \mathrm{ha}^{-1}$ for
Namulonge and $10.0 \mathrm{t} \cdot \mathrm{ha}^{-1}$ for Kachwekano. However, some accessions had higher storage root yields than respective means at both locations. At Kachwekano, storage root starch and sucrose contents were, respectively, higher and lower than at Namulonge (Table 3). The lowest root sucrose contents for farmer varieties were $4.3 \%$ and $4.7 \%$ at Namulonge and Kachwekano, respectively. At Namulonge, means for protein, $\beta$-carotene, $\mathrm{Fe}, \mathrm{Zn}$, and calcium were slightly higher than at Kachwekano. Maximum values for $\beta$-carotene were high at both locations, whereas the mean values for $\beta$ carotene were low (approximately two-thirds 
of the farmer varieties used in the study were white-fleshed). The $\mathrm{CV}$ ( $\mathrm{CV}$ given as a percentage) values for observed traits were low to moderate, except storage root yield and $\beta$ carotene content (greater than 30\%).

The $\sigma_{G}^{2}$ variance component was significant $(P<0.01)$ for all traits, except sucrose content (Table 4). For several observed traits, the $\sigma_{L}^{2}$, variance component was not significant $(P>$ $0.05)$, except starch, $\beta$-carotene, Fe, and $\mathrm{Zn}$. In contrast, the $\sigma_{G x L}^{2}$ variance component was significant $(P<0.01)$ for all traits. The $\sigma_{G}^{2}$ : $\sigma_{G x L}^{2}$ ratios were high (1:0.1 for $\beta$-carotene content) to extremely low (1:9.32 for sucrose content). It should be noted that the $\sigma_{G}^{2}$ : $\sigma_{G x L}^{2}$ ratio for sucrose is extreme for a quality trait. Mainly as a result of the magnitude of $\sigma_{G}^{2}: \sigma_{G x L}^{2}$ ratios within the interval $1: 0.5$ and 1:3.0 for most traits as well as the number of locations (2), the operational broad sense heritabilities $\left(\mathrm{h}^{2}\right)$ were moderate $(0.3$ to 0.6$)$ for most traits and only high for $\beta$-carotene content (0.94).

The population means (across varieties, locations, and replications) for storage root yield were low $\left(8.6 \mathrm{t} \cdot \mathrm{ha}^{-1}\right)$ (Table 5) but higher than the national average of $4.2 \mathrm{t} \cdot \mathrm{ha}^{-1}$ (Yanggen and Nagujja, 2006). Compared with averages given for cultivated sweetpotato clones of the world, higher population means for DM (32.1\%) and starch content (64.4\%) were observed. In contrast, sucrose population mean $(10.3 \%)$ was clearly low. The population means observed for $\mathrm{Fe}, \mathrm{Zn}$, calcium, and magnesium were $21.6 \mathrm{ppm}, 10.9 \mathrm{ppm}, 1950 \mathrm{ppm}$, and 626 ppm, respectively. However, an important finding was that nearly all light to deep OFSP famer varieties clearly contain provitamin A $\beta$-carotene. For the OFSP control ('Resisto'), a $\beta$-carotene content of $271 \mathrm{ppm}$ was observed. Several OFSP farmer varieties, namely 'Carrot_C' (259 ppm), 'Carrot Dar' (272 ppm), 'Ejumula' (240 ppm), 'Mayai' (264 ppm), and 'Zambezi' (233 ppm), exhibited similar or slightly different $\beta$-carotene contents as the control. For these OFSP accessions, high DM contents $(\approx 33 \%)$, elevated starch contents ( $\approx 58 \%$ to $66.6 \%$ dry weight basis), and low to moderate sucrose contents $(\approx 9.8 \%$ and $13.7 \%$ dry weight basis) were also observed. However, low sucrose contents $(6.4 \%$ to $7.4 \%$ ) were also observed in several whitefleshed varieties such as 'Bungoma', 'K-207', 'K-37', and 'KBL632 Nyinakamanzi'. Two OFSP varieties ('Rwanda' $=169$ ppm; 'Abu- ket1' $=159 \mathrm{ppm}$ ) were observed with moderately high $\beta$-carotene contents. It should be noted that for these two varieties, only low to medium DM contents were observed [in the case of 'Rwanda' significantly $(P<0.05)$ lower than 'Resisto']. An additional 12 famer varieties ('K-118', 'K-134', 'K-46', 'KMI61', 'MLE162 Nakahi', 'PAL161', 'Sowola6', 'Sponge', 'SRT34 Abuket2', 'SRT35 Anyumel', 'SRT52', and 'Sudan') were observed with significant but low $\beta$-carotene contents (33 to $82 \mathrm{ppm})$ and high to very high DM contents $(30.6 \%$ to $35.5 \%)$. Relatively high values for minerals were observed in OFSP (e.g., 'Carrot Dar' with values that correspond to $8.8 \mathrm{ppm}$ Fe, 4.5 ppm Zn, 695 ppm calcium, and 305 ppm magnesium on a fwb) as well as whitefleshed farmer varieties (i.e., 'MBR580 nylon' with values that correspond to $7.5 \mathrm{ppm} \mathrm{Fe}, 4.1$ ppm Zn, 901.5 ppm calcium, and 315.6 ppm magnesium on a fwb).

Moderate to high positive correlations were observed between trait pairs for DM and starch $(r=0.620)$, protein and $\mathrm{Fe}(r=0.810)$, protein and $\mathrm{Zn}(r=0.796), \mathrm{Fe}$ and $\mathrm{Zn}(r=$ $0.859), \mathrm{Fe}$ and magnesium $(r=0.633)$, and calcium and magnesium $(r=0.837)$ in storage roots on basis of all accessions $(\mathrm{N}=90)$ used in the study (Table 6). A high negative correlation was observed for starch and sucrose $(r=$ -0.885 ) on the basis of all accessions used in the study. A separate analysis with only OFSP varieties ( $\mathrm{N}=32$ clones) revealed that there are positive correlations between $\beta$-carotene and mineral (Fe $r=0.446$; $\mathrm{Zn} r=0.379$; magnesium $r=0.374$; calcium $r=0.428$ ), and sucrose $(r=0.470)$ contents, although these are not strong (Table 6). Also, a moderate negative correlation between $\beta$-carotene and starch $(r=$ -0.521 ) was observed.

The \%RDA under the condition of a high intake ( $250 \mathrm{~g}$ fresh storage roots) and consumers 5 to 8 years old was high for $\beta$-carotene (350 to 450) in deep OFSP farmer varieties (i.e., 'Carrot_C', 'Carrot Dar', 'Ejumula', 'Mayai', and 'Zambezi'). It should be noted that the estimated \%RDA $\beta$-carotene for the control clone ('Resisto') was $350 \%$. Estimates of $\approx 50 \%$ (results not presented) for $\% \mathrm{RDA}$ $\beta$-carotene were obtained with small intakes $\approx 30 \mathrm{~g}$ fresh storage roots per day) of deep OFSP farmer varieties (variety names given previously). Many OFSP farmer varieties with light orange color and high DM and starch contents were observed with \%RDA $\beta$-carotene estimates of $50 \%$ to $90 \%$ ('Shinyanga', 'HMA493 Tanzania', 'K-118', 'K-134', 'K46', 'PAL161', 'Sowola6', 'SRT52', and 'Sudan'). On average, low to medium \%RDA was observed for $\mathrm{Fe}$ and $\mathrm{Zn}(17.5 \%)$, calcium (20\%), and magnesium (40\%) (Table 7). Several accessions were observed with \%RDA between $20 \%$ and $22 \%$ for $\mathrm{Fe}$ and $\mathrm{Znc}, 25 \%$ to $33 \%$ for calcium, and $50 \%$ to $66 \%$ for magnesium, which were significantly different from accessions below the population mean (LSD test).

\section{Discussion}

Our study focused on $\beta$-carotene, DM, sucrose, protein, starch, and mineral contents against the background of the contribution of sweetpotato to the food supply in EA. Whereas levels of root $\beta$-carotene and DM contents are fairly well documented for African germplasm, other quality traits are not, thus making results of this study the first of its kind. The more pronounced differences between locations for starch content in our study (Table 3 ) extend our knowledge by documenting the magnitude of this variability (Grüneberg et al., 2005; Saad, 1996). The CV for all traits at both locations were low (Table 3 ), except storage root yields and $\beta$-carotene contents. High $\mathrm{CV}$ values for storage root yield have been previously reported for sweetpotatoes (Grüneberg et al., 2005) but could have also resulted from small plots used in the present study. Experiments with large plots would be needed to generate reliable data for root yield performance of the accessions. The high $\mathrm{CV}$ values for $\beta$-carotene contents in this study can be explained by the low population mean (for all accessions including white- and cream-fleshed), whereas mean estimates for $\beta$-carotene contents varied considerably between accessions. The variance component $\sigma_{G x L}^{2}$ was unexpectedly higher for starch and sucrose contents (Table 4). However, CV values for both traits at each location were low. The locations belong to distinct agroecological zones that differ greatly in altitude and crop duration for harvest (Table $2)$, which probably explains the high $\sigma_{G x L}^{2}$ estimates for starch (Grüneberg et al., 2005) and sucrose. Such extreme locations are most useful in testing accessions' adaptability and resistance to pest and diseases but less useful for nutritional quality breeding (Grüneberg

Table 4. Estimated variance components, variance component ratios in brackets, and operational broad-sense heritabilities of observed traits. ${ }^{2}$

\begin{tabular}{|c|c|c|c|c|c|}
\hline Trait & $\sigma_{G}^{2}$ & $\sigma_{L}^{2}$ & $\sigma_{G L}^{2}$ & $\overline{\sigma_{\varepsilon}^{2}}$ & $\mathrm{~h}^{2}$ \\
\hline Protein content of storage roots, $\%^{2} \mathrm{DM}$ & $0.32 * *(1)$ & $0.06(0.18)$ & $0.34 * *(1.05)$ & $0.94(2.94)$ & 0.44 \\
\hline Starch content of storage roots, $\%^{2} \mathrm{DM}$ & $5.31 * *(1)$ & $29.78 * *(5.61)$ & $13.88 * *(2.62)$ & $4.24(0.80)$ & 0.40 \\
\hline$\beta$-carotene content of storage roots, $\mathrm{ppm}^{2} \mathrm{DM}$ & $4362 * *(1)$ & $60 * *(0.01)$ & $430 * *(0.10)$ & $183(0.04)$ & 0.94 \\
\hline Iron content of storage roots, $\mathrm{ppm}^{2} \mathrm{DM}$ & $1.97 * *(1)$ & $8.72 * *(4.42)$ & $2.63 * *(1.33)$ & $4.54(2.30)$ & 0.45 \\
\hline Zinc content of storage roots, $\mathrm{ppm}^{2} \mathrm{DM}$ & $0.81 * *(1)$ & $3.80 * *(4.70)$ & $0.64 * *(0.79)$ & $1.59(1.97)$ & 0.53 \\
\hline
\end{tabular}

* Significant at the 0.05 level.

** Significant at the 0.01 level.

${ }^{\mathrm{z}}$ Variance components: $\sigma_{G}^{2}=$ genotypes; $\sigma_{L}^{2}=$ locations; $\sigma_{G x L}^{2}=$ genotype-location interactions; $\sigma_{\varepsilon}^{2}=$ error; $\mathrm{h}^{2}=$ operational broad-sense heritability . $\mathrm{DM}=$ dry matter. 


\begin{tabular}{|c|c|c|c|c|c|c|c|c|c|c|}
\hline \multirow[b]{2}{*}{ Farmer variety } & \multicolumn{10}{|c|}{ Observed traits ${ }^{z}$} \\
\hline & $\overline{\mathrm{YLD}\left(\mathrm{t} \cdot \mathrm{ha}^{-1}\right)}$ & DM (\%) & PRO (\%) & STA $(\%)$ & SUC (\%) & $\mathrm{BC}(\mathrm{ppm})$ & $\mathrm{Fe}(\mathrm{ppm})$ & $\mathrm{Zn}(\mathrm{ppm})$ & $\mathrm{Ca}(\mathrm{ppm})$ & $\mathrm{Mg}(\mathrm{ppm})$ \\
\hline$\overline{\text { APA343 }}$ & 5.3 & 32.5 & 5.7 & 63.9 & 11 & 12 & 19.7 & 9.7 & 1582 & 523 \\
\hline APA348 Liralira & 11.2 & 39.0 & 6.8 & 69.9 & - & 0 & 20 & 9.7 & 1748 & 607 \\
\hline APA352 Oketodede & 13.9 & 32.4 & 5.9 & 65.8 & 10.1 & 0 & 19.6 & 10.3 & 1587 & 478 \\
\hline APA365 Anam Anam & 12.3 & 33.0 & 5.7 & 67.1 & 8.9 & 0 & 20.1 & 10.4 & 1789 & 540 \\
\hline ARA208 Ombivu & 12.2 & 29.6 & 8.2 & 66.3 & 9.9 & 0 & 23.2 & 12.4 & 1550 & 401 \\
\hline ARA214 & 8.4 & 31.9 & 6.2 & 64.3 & 9.6 & 27 & 19.9 & 10.3 & 1500 & 520 \\
\hline ARA244 Shinyanga & 14.3 & 24.7 & 5.3 & 57.7 & 14 & 64 & 20.2 & 9.3 & 1685 & 561 \\
\hline Bunduguza & 5 & 35.3 & 6 & 66.6 & 10.7 & 0 & 19.8 & 8.6 & 2033 & 660 \\
\hline Bungoma & 11.9 & 33.4 & 6.2 & 67.5 & 6.4 & 0 & 20.8 & 10.1 & 1699 & 644 \\
\hline Carrot_C & 5.5 & 33.2 & 8.2 & 58.7 & 13.7 & 259 & 26.1 & 12.7 & 2591 & 924 \\
\hline Carrot Dar & 7.8 & 31.1 & 8 & 58.2 & 13.7 & 272 & 28.4 & 14.4 & 2232 & 981 \\
\hline Dimbuka & 16.8 & 32.2 & 7.5 & 67.1 & 8.3 & 0 & 21.2 & 11.3 & 1778 & 539 \\
\hline Ejumula & 8.4 & 32.7 & 7.4 & 58 & 13.4 & 240 & 23.8 & 11.4 & 2263 & 848 \\
\hline HMA 490 Kawogo & 1.3 & 32.6 & 6.1 & 65.5 & 8.6 & 0 & 20.1 & 10.4 & 1709 & 456 \\
\hline HMA493 Tanzania & 1.8 & 33.4 & 6.1 & 65.8 & 8.4 & 29 & 20.2 & 9.7 & 1996 & 682 \\
\hline IGA963 Nyongerabarenzi & 15.5 & 30.7 & 6.6 & 66.2 & 9.5 & 1 & 20.6 & 10.8 & 1525 & 374 \\
\hline $\mathrm{K}-118$ & 5.5 & 30.7 & 7.2 & 62.8 & 11.6 & 38 & 21.4 & 11.5 & 1350 & 470 \\
\hline K-134 & 10.3 & 31.9 & 6.7 & 64.5 & 10.5 & 40 & 21.1 & 11.1 & 1885 & 616 \\
\hline K-207 & 5.8 & 37.4 & 5.8 & 67.5 & 7.4 & 0 & 20.4 & 9.7 & 2888 & 857 \\
\hline K-37 & 2.8 & 34.1 & 4.7 & 66.6 & 7.4 & 25 & 18 & 8.2 & 2426 & 665 \\
\hline $\mathrm{K}-46$ & 4.5 & 33.7 & 6.6 & 62.9 & 11.3 & 48 & 21.3 & 10.7 & 2522 & 730 \\
\hline KBL627 Mukazi & 8.1 & 35.8 & 6.6 & 64.4 & 12.4 & 0 & 22.7 & 10.9 & 2053 & 747 \\
\hline KBL632 Nyinakamanzi & 7.1 & 31.3 & 6.6 & 68 & 7.4 & 1 & 20.9 & 11.4 & 2128 & 694 \\
\hline KBL640 Africare & 15.3 & 30.2 & 6.5 & 63.6 & 11.4 & 15 & 20.2 & 9.9 & 1392 & 467 \\
\hline KMI56 Opira & 10.6 & 31.3 & 6.8 & 65 & 9.5 & 0 & 22.9 & 11.2 & 1978 & 763 \\
\hline KMI59 Kampala & 11.6 & 32.6 & 7.1 & 63.8 & 9.8 & 0 & 22.9 & 10.1 & 1904 & 651 \\
\hline KMI61 & 7.9 & 33.4 & 7.4 & 64.4 & 10.5 & 75 & 23 & 11.3 & 1333 & 496 \\
\hline KMI78 Osukari & 6.5 & 31.5 & 8.4 & 66.1 & 8.6 & 0 & 22 & 11.8 & 1543 & 531 \\
\hline KMI81 Ikala & 11.7 & 25.6 & 7.3 & 60 & 12.1 & 28 & 22.7 & 12.6 & 1594 & 495 \\
\hline KMI83 Ikala2 & 11.9 & 29.9 & 7.4 & 63.2 & 11.7 & 11 & 21.2 & 10.8 & 1620 & 507 \\
\hline KML883 Silkempya & 13.8 & 35.1 & 6.2 & 68.7 & 8 & 0 & 20.1 & 9.4 & 1931 & 485 \\
\hline KRE716 nylon & 2.5 & 36.1 & 6.9 & 66.7 & 8.3 & -1 & 22.8 & 11.6 & 2569 & 816 \\
\hline KRE726 Kwezikumwe & 16.6 & 31.7 & 5.9 & 69.3 & 8.3 & 9 & 19.2 & 10.7 & 1426 & 445 \\
\hline KRE733 Kitambi & 3.8 & 35.2 & 6.3 & 66.4 & 8.6 & 0 & 21.9 & 11 & 1977 & 661 \\
\hline KSR673 Mabereikumi & 6.6 & 33.5 & 6.2 & 67.4 & 7.5 & 0 & 21.1 & 11.3 & 1505 & 365 \\
\hline KSR652 Mugumire & 1.9 & 34.9 & 7.5 & 66.9 & 8.9 & 1 & 21.1 & 10.9 & 2029 & 412 \\
\hline KSR662 Kakoba & 7.5 & 32.7 & 4.8 & 68 & 7.9 & 1 & 18.3 & 9.6 & 2313 & 568 \\
\hline KSR664 Mulererabana & 5.8 & 31.4 & 7.5 & 66.8 & 8.4 & 1 & 22.7 & 10.9 & 2056 & 738 \\
\hline KSR675 Nora II & 7.2 & 33.2 & 6.9 & 64.7 & 10.5 & 0 & 24 & 11.1 & 1897 & 730 \\
\hline Kunykubiongo & 15 & 29.3 & 6.2 & 63.4 & 10.1 & 0 & 21.3 & 10.2 & 1866 & 565 \\
\hline Kyabafuriki & 10.3 & 27.4 & 7.5 & 63.4 & 10.2 & 0 & 22.8 & 12.4 & 1969 & 492 \\
\hline LIR257 Otada & 11.7 & 32.7 & 6.7 & 67.8 & 6.7 & 0 & 20.3 & 9.5 & 1810 & 582 \\
\hline LIR296 & 15.5 & 32.6 & 6.5 & 63.2 & 11.6 & 0 & 19.4 & 9.7 & 1742 & 564 \\
\hline Mayai & 6.8 & 33.2 & 7.3 & 66.6 & 9.8 & 264 & 22.5 & 10.8 & 2177 & 761 \\
\hline MBR 539 Kitekamaju & 6.5 & 32.5 & 6.7 & 69.3 & 5.6 & 1 & 20.8 & 11.5 & 1934 & 530 \\
\hline MBR524 Nkwasahansi & 1.1 & 31.5 & 7.5 & 62.1 & 12.1 & 1 & 25.2 & 11.7 & 1904 & 639 \\
\hline MBR536 Karebe & 15 & 31.3 & 5.1 & 65.3 & 10.7 & 0 & 19.4 & 10.7 & 2120 & 633 \\
\hline MBR552 Kahungezi & 9.3 & 33.9 & 7.3 & 66.8 & 9.8 & 0 & 21.2 & 11.2 & 1986 & 644 \\
\hline MBR580 nylon & 4.8 & 27.4 & 6.5 & 58.4 & 13.7 & 0 & 27.4 & 14.8 & 3290 & 1152 \\
\hline APA343 & 5.3 & 32.5 & 5.7 & 63.9 & 11 & 12 & 19.7 & 9.7 & 1582 & 523 \\
\hline MBR600 Kisakyabikiramaria & 5.8 & 30.9 & 7.7 & 65.5 & 9.5 & 0 & 23.5 & 12.3 & 1611 & 520 \\
\hline MLE 166 & 6 & 35.3 & 5.9 & 69.2 & 7.6 & 5 & 21.3 & 10.7 & 2212 & 733 \\
\hline MLE162 Nakahi & 10.2 & 32.9 & 6.5 & 64.9 & 10.1 & 45 & 20.7 & 10.1 & 1801 & 611 \\
\hline MLE163 Kyebandula & 9.5 & 36.6 & 8 & 66.6 & 8.6 & -1 & 24.4 & 12 & 2382 & 863 \\
\hline MLE165 Namafumbiro & 5.9 & 30.7 & 6.2 & 64.7 & 10.2 & 0 & 21.8 & 11.5 & 2337 & 755 \\
\hline MLE173 Kijovu & 5.3 & 29.7 & 7.4 & 64.5 & 9.8 & -1 & 23.7 & 11.4 & 1855 & 506 \\
\hline MLE184 Manafayereta & 6.4 & 32.3 & 8.1 & 64.7 & 9.9 & 0 & 23.3 & 13.5 & 1814 & 415 \\
\hline MSK1025 Bitambi & 5.4 & 34.3 & 5.9 & 68.3 & 7.7 & 0 & 19.9 & 10.5 & 2588 & 775 \\
\hline MSK1047 Bwanjure & 6.6 & 30.7 & 6.8 & 65 & 9.2 & 0 & 22.2 & 11.1 & 1651 & 438 \\
\hline Nyaguta & 5.4 & 33.2 & 7.1 & 62.7 & 10.9 & 0 & 24.8 & 11.3 & 2659 & 1046 \\
\hline Nyandere & 14.2 & 34.9 & 6.2 & 66.2 & 8.9 & 0 & 19.5 & 10.5 & 1527 & 473 \\
\hline Nyathiodiewo & 16.2 & 30.2 & 6.2 & 64.8 & 9.6 & 0 & 19.7 & 10.1 & 1650 & 566 \\
\hline Nyatonge & 8.4 & 33.4 & 5.9 & 67.8 & 9.2 & 0 & 19.5 & 9.9 & 2003 & 632 \\
\hline Obuogo1 & 3.7 & 36.3 & 7.3 & 64 & 11.2 & 0 & 22.8 & 10.1 & 2073 & 780 \\
\hline Obuogo2 & 4.1 & 34.5 & 6.9 & 67.7 & 8 & 0 & 22 & 9.8 & 1755 & 657 \\
\hline Oguroiwe & 6.6 & 33.8 & 6 & 67.5 & 9.6 & 0 & 19.8 & 10.4 & 1226 & 358 \\
\hline PAL153 Abukoki & 7.7 & 29.7 & 4.3 & 67 & 8.9 & -1 & 16.6 & 9 & 1639 & 309 \\
\hline PAL161 & 6.8 & 35.5 & 6.8 & 65.2 & 9.3 & 33 & 20.2 & 10.5 & 1609 & 602 \\
\hline Pipi & 7.7 & 33.2 & 6.4 & 65 & 10.2 & 13 & 19 & 10 & 1903 & 602 \\
\hline Resisto & 7.8 & 24.8 & 7.6 & 53.5 & 15.7 & 271 & 24.1 & 12.7 & 1821 & 646 \\
\hline Sowola (389 A) & 13.2 & 33.3 & 7.2 & 66.4 & 9.8 & 0 & 21.1 & 11.1 & 1603 & 469 \\
\hline Sowola_6 & 9.9 & 30.6 & 8 & 62.2 & 10.3 & 54 & 24.6 & 12.5 & 2302 & 770 \\
\hline Sponge & 11.4 & 32.4 & 6 & 65.1 & 10 & 48 & 19.7 & 10.2 & 2039 & 595 \\
\hline
\end{tabular}


Table 5. (Continued) Clone means of farmer varieties for observed traits across locations.

\begin{tabular}{|c|c|c|c|c|c|c|c|c|c|c|}
\hline \multirow[b]{2}{*}{ Farmer variety } & \multicolumn{10}{|c|}{ Observed traits ${ }^{\mathrm{z}}$} \\
\hline & YLD (t.ha $\left.{ }^{-1}\right)$ & $\mathrm{DM}(\%)$ & PRO (\%) & STA $(\%)$ & SUC (\%) & $\mathrm{BC}(\mathrm{ppm})$ & $\mathrm{Fe}(\mathrm{ppm})$ & $\mathrm{Zn}(\mathrm{ppm})$ & $\mathrm{Ca}(\mathrm{ppm})$ & $\mathrm{Mg}(\mathrm{ppm})$ \\
\hline SRT 14 Nora & 14.1 & 32 & 6.6 & 62.8 & 11.7 & 0 & 21.2 & 9.5 & 2156 & 593 \\
\hline SRT01 Osapat & 9.5 & 33.6 & 6.2 & 66.8 & 9.6 & 0 & 19.5 & 10 & 1660 & 525 \\
\hline SRT02 Araka white & 10.3 & 33 & 7.3 & 65.8 & 9.6 & 0 & 22.5 & 11.5 & 1608 & 440 \\
\hline SRT30 Nyara & 13.9 & 29 & 7.6 & 58.3 & 13.8 & 22 & 22.9 & 11.7 & 1891 & 644 \\
\hline SRT33 Abuket1 & 11.6 & 27.7 & 7.1 & 58.2 & 14.6 & 159 & 23.1 & 12.4 & 1938 & 670 \\
\hline SRT34 Abuket2 & 13.2 & 31 & 6.6 & 59.5 & 14.5 & 51 & 20.3 & 10.1 & 1762 & 587 \\
\hline SRT35 Anyumel & 9.4 & 31.6 & 6.9 & 63.8 & 10.6 & 82 & 22.7 & 11.2 & 1871 & 636 \\
\hline SRT39 Rwanda & 12.2 & 20.1 & 5.4 & 51.1 & 17 & 169 & 22.7 & 10.7 & 2179 & 771 \\
\hline SRT40 Mary & 10.6 & 35.9 & 6.4 & 64.7 & 10.7 & -1 & 22.1 & 10.8 & 2916 & 918 \\
\hline SRT49 Sanyuzameza & 5.8 & 35.3 & 8 & 65.7 & 9.3 & 0 & 24.3 & 12.3 & 2414 & 976 \\
\hline SRT52 & 4.1 & 32.5 & 7.5 & 64.2 & 11 & 35 & 23.4 & 11.7 & 2644 & 892 \\
\hline Sudan & 6.1 & 32.2 & 6.3 & 64.6 & 10.6 & 44 & 20.6 & 10.2 & 1571 & 646 \\
\hline Tororo3 & 5.1 & 32.9 & 5.2 & 65.2 & 9.3 & 0 & 18.1 & 7.9 & 2238 & 537 \\
\hline Ukerewe & 13.7 & 34.6 & 5.7 & 65.7 & 11.2 & 0 & 18.4 & 9.6 & 1536 & 421 \\
\hline Wagaborige & 7.3 & 32.2 & 6 & 65.2 & 11.9 & 0 & 19.9 & 8.7 & 1493 & 498 \\
\hline Wera & 4.2 & 29.9 & 7 & 50.1 & 28.5 & 1 & 26.1 & 13.1 & 2544 & 1004 \\
\hline Zambezi & 6.7 & 29.5 & 7 & 62 & 11.1 & 233 & 22.9 & 12.9 & 2631 & 884 \\
\hline Least significant difference $(0.05)$ & 6.6 & 2.8 & 1.4 & 2.9 & 2.5 & 19 & 3.0 & 1.8 & 534 & 219 \\
\hline Population mean & 8.6 & 32.1 & 6.7 & 64.4 & 10.3 & 30.6 & 21.6 & 10.9 & 1950 & 628 \\
\hline
\end{tabular}

${ }^{\mathrm{z}}$ Observed traits: YLD $=$ storage root yield, $\mathrm{t} \cdot \mathrm{ha}^{-1} ; \mathrm{DM}=$ dry matter content of storage roots, $\% ;$ PRO = protein content of storage roots, $\%$ DM; STA = starch content of storage roots, \% DM; SUC = sucrose content of storage roots, \% DM; BC = $\beta$-carotene content of storage roots, ppm DM; Fe = iron content of storage roots, ppm DM; $\mathrm{Zn}=$ zinc content of storage roots, $\mathrm{ppm} \mathrm{DM} ; \mathrm{Ca}=$ calcium content of storage roots, $\mathrm{ppm} \mathrm{DM}$; $\mathrm{Mg}=\mathrm{magne}$ (ium content of storage roots, $\mathrm{ppm} \mathrm{DM}$.

Table 6. Pearson correlation coefficients among observed traits in East African sweetpotatoes. ${ }^{\mathrm{z}}$

\begin{tabular}{|c|c|c|c|c|c|c|c|c|c|}
\hline & YLD & DM & PRO & STA & SUC & $\mathrm{BC}$ & $\mathrm{Fe}$ & $\mathrm{Zn}$ & $\mathrm{Ca}$ \\
\hline \multicolumn{10}{|c|}{ Estimates based on all farmer varieties $(N=89)$} \\
\hline DM & -0.178 & & & & & & & & \\
\hline PRO & -0.095 & 0.018 & & & & & & & \\
\hline Sta & -0.015 & 0.620 & -0.265 & & & & & & \\
\hline Suc & -0.023 & -0.472 & 0.147 & -0.885 & & & & & \\
\hline $\mathrm{BC}$ & -0.061 & -0.275 & 0.131 & -0.467 & 0.351 & & & & \\
\hline $\mathrm{Fe}$ & -0.188 & -0.176 & 0.810 & -0.505 & 0.368 & 0.232 & & & \\
\hline $\mathrm{Zn}$ & -0.123 & -0.205 & 0.796 & -0.361 & 0.231 & 0.205 & 0.859 & & \\
\hline $\mathrm{Ca}$ & -0.299 & 0.088 & 0.228 & -0.214 & 0.163 & 0.149 & 0.428 & 0.276 & \\
\hline $\mathrm{Mg}$ & -0.276 & 0.067 & 0.397 & -0.301 & 0.234 & 0.232 & 0.633 & 0.433 & 0.837 \\
\hline \multicolumn{10}{|c|}{ Estimated based on orange-fleshed farmer varieties $(N=32)$} \\
\hline DM & -0.258 & & & & & & & & \\
\hline PRO & -0.148 & 0.064 & & & & & & & \\
\hline Sta & -0.071 & 0.708 & -0.199 & & & & & & \\
\hline Suc & 0.050 & -0.586 & 0.181 & -0.917 & & & & & \\
\hline $\mathrm{BC}$ & -0.188 & -0.209 & 0.213 & -0.521 & 0.470 & & & & \\
\hline $\mathrm{Fe}$ & -0.172 & -0.205 & 0.805 & -0.493 & 0.429 & 0.446 & & & \\
\hline $\mathrm{Zn}$ & -0.140 & -0.167 & 0.855 & -0.375 & 0.325 & 0.379 & 0.899 & & \\
\hline $\mathrm{Ca}$ & -0.355 & 0.050 & 0.315 & -0.137 & 0.061 & 0.374 & 0.469 & 0.324 & \\
\hline $\mathrm{Mg}$ & -0.350 & 0.006 & 0.505 & -0.232 & 0.151 & 0.428 & 0.705 & 0.560 & 0.857 \\
\hline
\end{tabular}

${ }^{z}$ Observed traits: $\mathrm{YLD}=$ storage root yield, $\mathrm{t} \cdot \mathrm{ha}^{-1} ; \mathrm{DM}=$ dry matter content of storage roots, $\%$; $\mathrm{PRO}=$ protein content of storage roots, \% DM; STA = starch content of storage roots, \% DM; SUC = sucrose content of storage roots, $\% \mathrm{DM} ; \mathrm{BC}=\beta$-carotene content of storage roots, ppm $\mathrm{DM} ; \mathrm{Fe}=$ iron content of storage roots, ppm DM; $\mathrm{Zn}=$ zinc content of storage roots, ppm DM; $\mathrm{Ca}=$ calcium content of storage roots, ppm DM; $\mathrm{Mg}=$ magnesium content of storage roots, ppm DM.

et al., 2009). The extreme locations result in lower heritabilities for improvement of quality traits, which was also observed in this study (Table 4). This merits further studies with a fraction of the varieties used in this study. Nevertheless, the variance component $\sigma_{G}^{2}$ was significant $(P<0.01)$ for all the observed traits except storage root sucrose contents, which indicates significant differences between accession means. Owing to the magnitude of $\sigma_{G x L}^{2}$ estimates and that locations were in distinct ecogeographical zones, we set genotype and location as fixed factors for a multiple comparison of accessions by the LSD test. Hence, LSD values at the 0.05 level might be underestimated but do not affect the evidence that differences below the LSD values given (Table 5) are not significantly different.
In contrast to germplasm from other regions (Woolfe, 1992), the EA accessions have clearly higher DM ( $\approx 32 \%$ to $33 \%)$, higher starch $(\approx 65 \% \mathrm{DM})$, and lower sucrose $(\approx 10 \% \mathrm{DM})$ contents. It appears that sweetpotato in EA has on average a moderate sweetness and several accessions such as 'Bungoma', 'K-207', 'K-37', and 'KBL632 Nyinakamanzi' have very low sucrose $(\approx 7.5 \% \mathrm{DM})$ content. These quality attributes make the crop more attractive to be used as a starchy staple in EA compared with such other regions of the world as South Asia and Central and South America where sweetpotato is consumed in low amounts. However, sweetness after cooking or boiling is also determined by enzymatic conversion of starch to maltose (Kays et al., 2005) and not only by the sucrose content we observed in fresh storage roots.

The study found five OFSP farmer varieties ('Carrot_C', 'Carrot Dar', 'Ejumula', 'Mayai', and 'Zambezi') with high $\beta$-carotene contents similar to the control variety 'Resisto' (Table $5)$. The $\beta$-carotene estimates compare well with those reported for OFSP accessions with low storage root DM (Grüneberg et al., 2005; Purcell, 1962; Purcell and Walter, 1968). $\beta$ carotene content of 'Resisto' in the present study is lower than previous estimates (Laurie, 2008). The variety 'Resisto' is typical for the taste group "OFSP moist and sweet" (Martin and Jones, 1986) and had a storage root DM content of $24.8 \%$ and a storage root starch content of $53.5 \%$ (Table 5). Varieties such as 'Carrot_C', 'Carrot Dar', 'Ejumula', 'Mayai', and 'Zambezi' cannot be classified as "OFSP moist and sweet" but rather propose to be designated as "OFSP dry and starchy." These five OFSP farmer varieties all had DM content greater than $29.5 \%$ and starch content greater than $62.0 \%$. These estimates compare well with those obtained for many white-fleshed African farmer varieties in the same study. OFSP varieties with high DM and high starch contents make OFSP attractive to a much wider range of taste preferences. The 12 light OFSP accessions ('K-118', 'K-134', 'K-46, 'KMI61', 'MLE162 Nakahi', 'PAL161', 'Sowola6', 'Sponge', 'SRT34 Abuket2', 'SRT35 Anyumel', 'SRT52', and 'Sudan') with meaningful $\beta$-carotene (Table 5 ) are also important. The storage root DM and starch contents of these accessions were high, whereas sucrose contents were low and thus have attributes close to those of white-fleshed farmer varieties.

The results of this study are the first description of OFSP accessions that are high in DM and starch contents. This leads to the question where these "OFSP dry and starchy" are coming from in crop evolution. A molecular characterization of this material (Tumwegamire et al., 2011) has shown closer clustering of 
African OFSP with their sister WFSP accessions and clear genetic distances between African OFSP and non-African OFSP germplasm. Breeders in Africa have observed that open-pollinated white-fleshed accessions result in segregation of OFSP at low frequencies (Mwanga et al., 2003).

The potential to alleviate VAD through use of deep OFSP accessions like 'Carrot_C', 'Carrot Dar', 'Ejumula', 'Mayai', and 'Zambezi' is possibly very high in Uganda and other areas where daily sweetpotato consumption is high. These accessions showed at least $350 \%$ RDA $\beta$-carotene for the children aged 5 to 8 years with routine intake quantities found in Uganda (Table 7). This suggests that these varieties could address VAD in many other areas across the world, including South and East Asia and northeastern states of Brazil where VAD prevalence is high and per-capita consumption of sweetpotato is low. For example, 'Carrot_C' could provide $100 \%$ of RDA provitamin A intake with a modest 70 $\mathrm{g}$ of cooked roots per day. The potential to alleviate VAD using OFSP has been demonstrated (Low et al., 2001, 2007; van Jaarsveld et al., 2005). However, the challenge has been reluctance by farmers to grow and consume "OFSP moist and sweet" varieties, a situation that should possibly change given the "OFSP dry and starchy" accessions found in this study. Additionally, the light orange-fleshed accessions have been found to contribute significantly to RDA $\beta$-carotene in the range between $50 \%$ to $90 \%$ (Table 7 ).

The storage root mineral $(\mathrm{Fe}=21.6 \mathrm{ppm}$, $\mathrm{Zn}=10.9 \mathrm{ppm}$, calcium $=1950 \mathrm{ppm}$, and magnesium $=626 \mathrm{ppm})$ and protein $(6.7 \%)$ contents observed in the present study are in the range previously reported by Bradbury and Holloway (1988), Courtney (2007), Grüneberg et al. (2009), and Woolfe (1992). Percent RDA for magnesium is notably higher and approaches $50 \%$ of daily needs in many accessions. Iron, $\mathrm{Zn}$, and calcium had mean \%RDA of $17.3,17.4$, and 19.6, respectively. In areas with high sweetpotato consumption, farmer varieties like 'Carrot_C', 'Carrot Dar', 'KRE nylon', 'MLE163 Kyebandula' and 'SRT49 Sanyuzameza' can contribute to the intake of $\mathrm{Fe}, \mathrm{Zn}$, calcium, and magnesium (Table 7) but cannot alleviate respective mineral deficiencies at the current storage root concentrations. Breeding efforts, particularly in areas with high sweetpotato consumption, have to double $\mathrm{Fe}, \mathrm{Zn}$, and calcium contents in storage roots to reach $\% \mathrm{RDA}$ of $\approx 50 \%$ to achieve impact. In regions with low sweetpotato consumption and high VAD, breeders should mainly target high $\beta$-carotene content and consumer acceptance.

The correlation matrix (Table 6) is consistent with those reported for sweetpotato (Collins and Walter, 1982; Courtney, 2007; Grüneberg et al., 2009; Saad, 1996). The positive correlations between $\beta$-carotene and mineral and sucrose contents suggest the possibility of an indirect improvement of the latter through selection for higher $\beta$-carotene (Grüneberg et al., 2009). The challenge, however, is simultaneous improvement of DM and $\beta$-carotene
Table 7. Percent recommended daily intake (\%RDA) contribution of micronutrients based on $250 \mathrm{~g}$ fresh sweetpotato root consumption per day for different farmer varieties.

\begin{tabular}{|c|c|c|c|c|c|}
\hline \multirow[b]{2}{*}{ Farmer varieties } & \multicolumn{5}{|c|}{ RDA contribution (\%) } \\
\hline & $\beta$-carotene & Iron & Zinc & Calcium & Magnesium \\
\hline$\overline{\text { APA343 }}$ & 21 & 16.0 & 15.7 & 16.0 & 32.7 \\
\hline APA348 Liralira & 0 & 19.5 & 18.9 & 21.3 & 45.5 \\
\hline APA352 Oketodede & 0 & 15.9 & 16.6 & 16.1 & 29.8 \\
\hline APA365 Anam Anam & 0 & 16.6 & 17.1 & 18.4 & 34.3 \\
\hline ARA208 Ombivu & -0.1 & 17.2 & 18.4 & 14.4 & 22.9 \\
\hline ARA214 & 44.4 & 15.8 & 16.3 & 14.9 & 31.8 \\
\hline ARA244 Shinyanga & 82.7 & 12.4 & 11.5 & 13.0 & 26.6 \\
\hline Bunduguza & -0.2 & 17.5 & 15.2 & 22.4 & 44.8 \\
\hline Bungoma & 0 & 17.3 & 16.8 & 17.7 & 41.3 \\
\hline Carrot_C & 447.6 & 21.6 & 21.0 & 26.8 & 58.9 \\
\hline Carrot Dar & 440.7 & 22.1 & 22.4 & 21.7 & 58.7 \\
\hline Dimbuka & -0.2 & 17.1 & 18.2 & 17.9 & 33.4 \\
\hline Ejumula & 409.4 & 19.5 & 18.7 & 23.1 & 53.4 \\
\hline HMA490 Kawogo & 0 & 16.4 & 16.9 & 17.4 & 28.6 \\
\hline HMA493 Tanzania & 50.9 & 16.8 & 16.2 & 20.8 & 43.7 \\
\hline IGA963 Nyongerabarenzi & 1.5 & 15.8 & 16.6 & 14.6 & 22.0 \\
\hline $\mathrm{K}-118$ & 60.3 & 16.4 & 17.7 & 12.9 & 27.7 \\
\hline $\mathrm{K}-134$ & 65.6 & 16.8 & 17.7 & 18.8 & 37.8 \\
\hline $\mathrm{K}-207$ & -0.2 & 19.0 & 18.2 & 33.8 & 61.7 \\
\hline $\mathrm{K}-37$ & 45.1 & 15.4 & 13.9 & 25.8 & 43.5 \\
\hline $\mathrm{K}-46$ & 83.2 & 17.9 & 17.9 & 26.5 & 47.3 \\
\hline KBL627 Mukazi & 0 & 20.3 & 19.5 & 23.0 & 51.4 \\
\hline KBL632 Nyinakamanzi & 1.5 & 16.4 & 17.8 & 20.8 & 41.7 \\
\hline KBL640 Africare & 23.6 & 15.2 & 15.0 & 13.2 & 27.1 \\
\hline KMI56 Opira & 0 & 17.9 & 17.6 & 19.3 & 45.9 \\
\hline KMI59 Kampala & 0 & 18.6 & 16.4 & 19.4 & 40.7 \\
\hline KMI61 & 130.2 & 19.2 & 18.8 & 13.9 & 31.9 \\
\hline KMI78 Osukari & 0.1 & 17.3 & 18.6 & 15.2 & 32.2 \\
\hline KMI81 Ikala & 37.4 & 14.6 & 16.1 & 12.8 & 24.4 \\
\hline KMI83 Ikala2 & 16.7 & 15.8 & 16.1 & 15.1 & 29.1 \\
\hline KML883 Silkempya & 0 & 17.7 & 16.5 & 21.2 & 32.8 \\
\hline KRE716 nylon & -1.7 & 20.6 & 20.9 & 29.0 & 56.7 \\
\hline KRE726 Kwezikumwe & 14.2 & 15.2 & 16.9 & 14.1 & 27.1 \\
\hline KRE733 Kitambi & 0 & 19.2 & 19.3 & 21.7 & 44.7 \\
\hline KSR673 Mabereikumi & 0 & 17.6 & 18.8 & 15.7 & 23.5 \\
\hline KSR652 Mugumire & 1.7 & 18.4 & 19.0 & 22.1 & 27.6 \\
\hline KSR662 Kakoba & 1.7 & 14.9 & 15.7 & 23.6 & 35.7 \\
\hline KSR664 Mulererabana & 1.5 & 17.8 & 17.0 & 20.2 & 44.6 \\
\hline KSR675 Nora II & 0 & 19.9 & 18.3 & 19.7 & 46.5 \\
\hline Kunykubiongo & 0 & 15.6 & 14.9 & 17.1 & 31.8 \\
\hline Kyabafuriki & 0 & 15.6 & 17.0 & 16.9 & 25.9 \\
\hline LIR257 Otada & -0.2 & 16.6 & 15.4 & 18.5 & 36.6 \\
\hline LIR296 & 0 & 15.8 & 15.8 & 17.7 & 35.4 \\
\hline Mayai & 456.5 & 18.6 & 17.9 & 22.6 & 48.6 \\
\hline MBR539 Kitekamaju & 1.4 & 16.9 & 18.6 & 19.6 & 33.2 \\
\hline MBR524 Nkwasahansi & 1.5 & 19.8 & 18.3 & 18.7 & 38.7 \\
\hline MBR536 Karebe & 0 & 15.2 & 16.7 & 20.7 & 38.1 \\
\hline MBR552 Kahungezi & 0 & 18.0 & 18.9 & 21.0 & 42.0 \\
\hline MBR560 Mugurusi & 0 & 18.2 & 18.9 & 19.0 & 37.1 \\
\hline MBR580 nylon & -0.1 & 18.7 & 20.3 & 28.1 & 60.6 \\
\hline MBR600 Kisakyabikiramaria & 0 & 18.1 & 19.0 & 15.5 & 30.9 \\
\hline MLE166 & 9.8 & 18.8 & 18.9 & 24.4 & 49.8 \\
\hline MLE162 Nakahi & 77.1 & 17.0 & 16.6 & 18.5 & 38.7 \\
\hline MLE163 Kyebandula & -1.7 & 22.3 & 22.0 & 27.3 & 60.8 \\
\hline MLE165 Namafumbiro & 0.1 & 16.8 & 17.7 & 22.4 & 44.6 \\
\hline MLE173 Kijovu & -1.4 & 17.6 & 16.9 & 17.2 & 28.8 \\
\hline MLE184 Manafayereta & 0 & 18.8 & 21.7 & 18.3 & 25.7 \\
\hline MSK1025 Bitambi & 0 & 17.1 & 17.9 & 27.7 & 51.1 \\
\hline MSK1047 Bwanjure & 0 & 17.0 & 17.1 & 15.8 & 25.8 \\
\hline Nyaguta & 0 & 20.6 & 18.8 & 27.6 & 66.8 \\
\hline Nyandere & 0 & 17.0 & 18.2 & 16.6 & 31.7 \\
\hline Nyathiodiewo & 0 & 14.8 & 15.3 & 15.5 & 32.8 \\
\hline Nyatonge & 0 & 16.3 & 16.5 & 20.9 & 40.6 \\
\hline Obuogol 1 & 0 & 20.7 & 18.3 & 23.5 & 54.5 \\
\hline Obuogo II & 0 & 18.9 & 16.8 & 18.9 & 43.6 \\
\hline Oguroiwe & 0 & 16.7 & 17.6 & 12.9 & 23.2 \\
\hline PAL153 Abukoki & -1.4 & 12.3 & 13.4 & 15.2 & 17.7 \\
\hline PAL161 & 60.7 & 17.9 & 18.7 & 17.9 & 41.1 \\
\hline Pipi & 22.5 & 15.8 & 16.6 & 19.7 & 38.4 \\
\hline Resisto & 350.1 & 14.9 & 15.7 & 14.1 & 30.8 \\
\hline Sowola (389A) & 0 & 17.5 & 18.4 & 16.7 & 30.0 \\
\hline Sowola_6 & 86.3 & 18.8 & 19.1 & 22.0 & 45.3 \\
\hline
\end{tabular}

(Continued on next page) 
Table 7. (Continued) Percent recommended daily intake (\%RDA) contribution of micronutrients based on $250 \mathrm{~g}$ fresh sweetpotato root consumption per day for different farmer varieties.

\begin{tabular}{lccccc}
\hline & \multicolumn{3}{c}{ RDA contribution (\%) } \\
\cline { 2 - 5 } Farmer varieties & $\beta$-carotene & Iron & Zinc & Calcium & Magnesium \\
\hline Sponge & 80.6 & 16.0 & 16.6 & 20.6 & 37.1 \\
SRT14 Nora & -0.1 & 17.0 & 15.2 & 21.5 & 36.5 \\
SRT01 Osapat & 0 & 16.4 & 16.8 & 17.4 & 34.0 \\
SRT02 Araka white & -0.2 & 18.5 & 18.9 & 16.6 & 27.9 \\
SRT30 Nyara & 32.5 & 16.6 & 16.9 & 17.2 & 35.9 \\
SRT33 Abuket_1 & 228.8 & 16.0 & 17.1 & 16.7 & 35.6 \\
SRT34 Abuket_2 & 82.2 & 15.7 & 15.6 & 17.0 & 35.0 \\
SRT35 Anyumel & 134.7 & 17.9 & 17.7 & 18.4 & 38.6 \\
SRT39 Rwanda & 176.5 & 11.4 & 10.7 & 13.7 & 29.7 \\
SRT40 Mary & -1.7 & 19.9 & 19.3 & 32.7 & 63.4 \\
SRT49 Sanyuzameza & 0 & 21.5 & 21.8 & 26.7 & 66.3 \\
SRT52 & 59.3 & 19.0 & 19.0 & 26.8 & 55.7 \\
Sudan & 72.9 & 16.6 & 16.4 & 15.8 & 39.9 \\
Tororo3 & 0.2 & 14.9 & 13.0 & 23.0 & 33.9 \\
Ukerewe & 0 & 15.9 & 16.6 & 16.6 & 28.0 \\
Wagaborige & 0 & 16.0 & 14.0 & 15.0 & 30.8 \\
Wera & 1.4 & 19.5 & 19.6 & 23.8 & 57.7 \\
Zambezi & 357.6 & 16.9 & 19.1 & 24.3 & 50.2 \\
Least significant difference (0.05) & 27.8 & 2.7 & 3.0 & 6.0 & 14.9 \\
Population mean & 47.9 & 17.3 & 17.4 & 19.6 & 38.9 \\
\hline
\end{tabular}

levels among the sweetpotato germplasm. Whereas starch and DM were positively correlated, they were both negatively correlated to $\beta$-carotene content. Similar observations are reported by Grüneberg et al. (2009).

In conclusion, East African sweetpotato germplasm is clearly higher in storage root $\mathrm{DM}$ and storage root starch contents and clearly lower in storage root sucrose contents compared with the cultivated sweetpotato of the rest of the world, especially the traditional OFSP. The study revealed that African OFSP farmer varieties such as 'Carrot_C', 'Ejumula', 'Carrot Dar', 'Mayai', and 'Zambezi' contain moderate to high levels of storage root DM and high levels of $\beta$-carotene and might be useful for better acceptance of OFSP in Africa as well as other regions of the world. Moreover, sweetpotato significantly adds to the mineral contribution in food supply (i.e., Fe, Zn, calcium, and magnesium) when sweetpotato is consumed frequently. The new OFSP accessions described in this study justify a category (or group) termed "OFSP dry and starchy" and this group may enhance consumer appeal toward a more nutritious sweetpotato, which increases the potential of OFSP to contribute to the alleviation of VAD.

\section{Literature Cited}

Aceto, M., O. Abollino, M.C. Bruzzoniti, E. Mentasti, C. Sarzanini, and M. Malandrino. 2002. Determination of metals in wine with atomic spectroscopy (flame-AAS, GF-AAS and ICP-AES). Food Addit. Contam. 19:126-133.

Black, R. 2003. Micronutrient deficiency: An underlying cause of morbidity and mortality. Bull. World Health Organ. 81:79.

Bouis, H. 2003. Micronutrient fortification of plants through plant breeding; Can it improve nutrition in Mana at low cost? Proc. Nutr. Soc. 62:403-411.

Bradbury, J.H. and W.D. Holloway. 1988. Chemistry of tropical root crops: Significance for nutrition and agriculture in the Pacific. ACIAR Monograph Ser. No. 6, Canberra.

Bridger, S. and M. Knowles. 2000. A complete method for environmental samples by simulta-
Hill, J., H.C. Becker, and P.M.A. Tigerstedt. 1998. Quantitative and ecological aspects of plant breeding. Chapman \& Hall, London, UK.

ICC. 1994. ICC determination of starch content by hydrochloric acid dissolution. ICC Standard No. 123/1, International Association for Cereal Science and Technology.

Kays, S.J., Y. Wang, and W.J. McLaurin. 2005. Chemical and geographical assessment of the sweetness of the cultivated sweetpotato clones of the world. J. Amer. Soc. Hort. Sci. 130:591591.

Laurie, S.M. 2008. Breeding crops for micronutrient density: A case for and current status, of orangefleshed sweetpotato. In: Faber, M., S.M. Laurie, and P.J. van Jaarsveld (eds.). Proc.of orangefleshed sweetpotato symposium, Pretoria, South Africa.

Lebot, V., A. Champagne, R. Malapa, and D. Shiley. 2009. NIR determination of major constituents in tropical root and tuber crop flours. J. Agr. Food Chem. 57:10539-10547.

Low, J., T. Walker, and R. Hijmans. 2001. The potential impact of orange-fleshed sweetpotatoes on vitamin A intake in sub-Saharan Africa. Presented at a regional workshop on food-based approaches to human nutrition deficiencies, 911 May 2001, Nairobi, Kenya.

neous axially viewed ICPAES following US EPA guidelines. Varian ICP-OES. No. 29.

CIP. 2005. Annual sub-project progress report. Biofortification of sweetpotato. Apr. 2010. $<$ http//: wwwcipotato.org/icers/3303.doc $>$.

Collins, W.W. and W.M. Walter. 1982. Potential for increasing nutritional value of sweetpotatoes, p. 355-363. In: Villareal, R.L. and T.D. Giggs (eds.). Sweetpotato. Proc. of the First International Symposium, AVRDC, Shanhua, Tianan.

Courtney, W.M. 2007. Genotypic variability and inheritance of iron, zinc in sweetpotato. MSc thesis, Department of Horticulture, Louisiana State University.

Cozzolino, D. and A. Moron. 2004. Exploiting the use of near infrared reflectance spectroscopy in legumes. Anim. Feed Sci. Technol. 111:161-173.

Ezell, B.D. and M.S. Wilcox. 1958. Variation in carotene content of sweet potatoes. Agric. Food Chem. 6:61-65.

FAOSTAT. 2007. May 2010. <http://faostat.fao.org/>.

Frossard, E., M. Bucher, F. Machler, A. Mozafar, and R. Hurrell. 2000. Review: Potential for increasing the content and bioavailability of $\mathrm{Fe}$, $\mathrm{Zn}$ and $\mathrm{Ca}$ in plants for human nutrition. Jr. of the Science of Food and Agriculture. p. 861879.

Grüneberg, W.J., K. Manrique, Z. Dapeng, and M Hermann. 2005. Genotype $\times$ environment interactions for a diverse set of sweet potato clones evaluated across varying ecogeographic conditions in Peru. Crop Sci. 45:2160-2171.

Grüneberg, W.J., R. Mwanga, M. Andrade, and J. Espinoza. 2009. Selection methods. Part 5: Breeding clonally propagated crops, p. 275322. In: Ceccarelli, S., E.P. Guimarães, and E. Weltzien (eds.). Plant breeding and farmer participation. FAO, Rome, Italy.

Haase, N.U. 2006. Rapid estimation of potato tuber quality by near-infrared spectroscopy. Starch. 58:268-273.

Hagenimana, V., E.E. Carey, S.T. Gichuki, M.A. Oyunga, and J.K. Imungi. 1999. Carotenoid contents in fresh, dried, and processed sweetpotato products. Ecol. Food Nutr. 37:455473.

Halgerson, J.L., C.C. Sheaffer, N.P. Martin, P.R. Peterson, and S.J. Weston. 2004. Near-infrared reflectance spectroscopy prediction of leaf and mineral concentrations in alfalfa. Agron. J. 96:344-351.
Low, J.W., M. Arimond, N. Osman, B. Cunguara, F. Zano, and D. Tschirley. 2007. A food-based approach introducing orange-fleshed sweet potatoes increased vitamin A intake and serum retinol concentrations in young children in rural Mozambique. J. Nutr. 137:1320-1327.

Lu, G., H. Huang, and D. Zhang. 2006. Application of near-infrared spectroscopy to predict sweetpotato starch thermal properties and noodle quality. J. Zhejiang Univ. Sci. B 7:475-481.

Martin, F.M. and A. Jones. 1986. Breeding sweet potatoes. Plant Breed. Rev. 4:313-345.

Mehrübeoglu, M. and G.L.P. Coté. 1997. Determination of total reducing sugars in potato samples using near-infrared spectroscopy. Cereal foods. WORLD 42:409-413.

Munoz, E.C., J.L. Rosado, P. Lopez, H.C. Furr, and H.I. Allen. 2000. Iron and zinc supplementation improves indicators of vitamin A status of Mexican preschoolers. Amer. J. Clin. Nutr. 71:789-794.

Mwanga, R.O.M., B. Odongo, C. Niringiye, A. Alajo, P.E. Abidin, R. Kapinga, S. Tumwegamire, B. Lemaga, J. Nsumba, and E.E. Carey. 2007. Release of two orange-fleshed sweetpotato cultivars 'SPK004' (Kakamega) and 'Ejumula' in Uganda. HortScience 42:1728-1730.

Mwanga, R.O.M., B. Odongo, C.N. Niringiye, A. Alajo, B. Kigozi, R. Makumbi, E. Lugwana, J. Namakula, I. Mpembe, R. Kapinga, B. Lemaga, J. Nsumba, S. Tumwegamire, and C.G. Yencho. 2009. 'NASPOT 7', 'NASPOT 8', 'NASPOT 9 O', 'NASPOT 10 O', and 'Dimbuka-Bukulula' sweetpotato. HortScience 44:828-832.

Mwanga, R.O.M., B. Odongo, C. Niringiye, D Zhang, G.C. Yencho, and R. Kapinga. 2003. Orange-fleshed sweetpotato breeding activities in Uganda. In: Nampala, M.P., J.S. Tenywa, A.W. Mwangombe, M. Osiru, R. Kawuki, and M. Biruma (eds.). African Crop Science Conference Proc. 6:103-107.

National Academy of Sciences. 2004. Dietary reference intakes (DRIs): recommended intakes for individuals. National Academy of Sciences, Institute of Medicine, Food and Nutrition Board. May 2010. <http://iom.edu/en/Global/News\%20 Announcements/ /media/Files/Activity\%20Files/ Nutrition/DRIs/DRISummaryListing2.ash $x>$.

Pfeiffer, W.H. and B. McClafferty. 2007. HarvestPlus: Breeding crops for better nutrition. Crop Sci. 47:88-105. 
Purcell, A.E. 1962. Carotenoids of Goldrush sweetpotato flakes. Food Technol. 16:99-102.

Purcell, A.E. and W.M. Walter. 1968. Carotenoids of Centennial variety sweet potato, Ipomoea batatas L. J. Agr. Food Chem. 16:769-770.

Rodriguez-Amaya, D.B., and M. Kimura. 2004. HarvestPlus handbook for carotenoid analysis. HarvestPlus Technical Monograph Series 2.

Saad, M.S. 1996. Genetics and variability of starch, protein, fiber and ash in sweetpotatoes from Malaysia. In: Rasco, E.T., Jr., and V.d.R. Amante (eds.). SAPPRAD on the fourth year of phase III, selected research papers July 1994-June 1995. Manila (Philippines). SAPPRAD. 2:203-210.

SAS Institute Inc. 1988. SAS/STAT user's guide, Release 6.03 ed. SAS Inst. Inc., Cary, NC.

SAS Institute Inc. 1997. SAS/STAT software: Changes and enhancements through Release 6.12 ed. SAS Inst. Inc., Cary, NC.

Scott, G.J., M.W. Rosegrant, and C. Ringler. 2000. Roots and tubers for the $21^{\text {st }}$ century: Trends, Projections and Policy Options. 2020 Brief 66: a 2020 vision for food, agriculture and the environment. International Food Policy Research Institute, Washington D.C.

Shenk, J.S. and M.O. Westerhaus. 1993. Analysis of agriculture and food products by near infrared reflectance spectroscopy. The Pennsylvania State University and Infrasoft International, State College, PA.
Sweeney, R.A. and P.R. Rexroad. 1987. Comparison of LECO FP-228 'Nitrogen Determinator' with AOAC copper catalyst Kjeldahl method for crude proteína. J. Amer. Off. Anal. Chem. 70:1028-1030.

Tumwegamire, S., R. Kapinga, D. Zhang, C. Crissman, and S. Agili. 2004. Opportunities for promoting orange-fleshed sweetpotato as mechanism for combating vitamin A deficiency in sub-Saharan Africa. African Crop Sci. Journal. 12:243-254.

Tumwegamire, S., P.R. Rubaihayo, D.R. LaBonte, W.J. Grüneberg, R. Kapinga, R.O.M. Mwanga, and F. Diaz. 2011. Genetic diversity in whiteand orange-fleshed sweetpotato farmer varieties from East Africa evaluated by simple sequence repeat (SSR). Markers. Crop Sci. (In Press).

Uganda Bureau of Statistics and Macro International Inc. 2007. Uganda Demographic and Health Survey 2006. Calverton, MD.

Utz, H.F. 2001. PLABSTAT. A computer program for statistical analysis of plant breeding experiments. Version 2F. Institute of Plant Breeding, Seed Science and Population Genetics. University of Hohenheim, Stuttgart, Germany.

van Jaarsveld, P.J., M. Faber, S.A. Tanumihardjo, P. Nestel, C.J. Lombard, and A.J.S. Benade. 2005. $\beta$-carotene-rich orange-fleshed sweetpotato improves the vitamin A status of primary school children assessed with the modified-relative-doseresponse test. Amer. J. Clin. Nutr. 81:1080-1087.
West, K.P. 2002. Extent of vitamin A deficiency among preschool children and women of reproductive age. J. Nutr. 132:S2857-S2866.

WHO. 2008. Worldwide prevalence of anaemia 19932005: WHO global database on anaemia. In: de Benoist, B., E. McLean, I. Egli and M. Cogswell (eds.). August 2010. <http://whqlibdoc.who.int/ publications/2008/9789241596657_eng.pdf>.

Woolfe, J.A. 1992. Sweetpotato: An untapped food resource. Cambridge University Press, Cambridge, UK.

Yanggen, D. and S. Nagujja. 2006. The use of orange-fleshed sweetpotato to combat Vitamin A deficiency in Uganda. A study of varietal preferences, extension strategies and post-harvest utilization. International Potato Center (CIP), Lima, Peru.

Young, M.W., D.K.L. MacKerron, and H.V. Davies. 1997. Calibration of near-infrared reflectance spectroscopy to estimate nitrogen concentration in potato tissues. Potato Res. 40:215-220.

Zum Felde, T., G. Burgos, J. Espinoza, R. Eyzaguirre, E. Porras, and W. Grüneberg. 2009. Screening for $\beta$-carotene, iron, zinc, starch, individual sugars and protein in sweetpotato germplasm by nearinfrared reflectance spectroscopy (NIRS). 15th Triennial Symposium of the International Society for Tropical Root Crops, Lima Peru. April 2010 $<\mathrm{http} / / /$ sol/research/ddgr/istrc-2009/ISTRC\% $202009 \% 20-\% 20 \mathrm{CD} / \mathrm{SESSION}-08$.pdf $>$. 